\title{
Corrigendum: Limitations of time resources in human relationships determine social structures
}

\author{
Masanori Takano and Ichiro Fukuda
}

Correction to: Palgrave Communications (2017) 3 Article number: 17014 doi:10.1057/palcomms.2017.14; Published 7 Mar 2017; Updated 24 May 2017

The original article did not include a link or reference to the study's supplementary information file.

The following now appears in the PDF version of the paper:

\section{Additional information}

Supplementary Information: accompanies this paper at http://www.palgrave-journals .com/palcomms

The article has been corrected online.

\footnotetext{
(i) This work is licensed under a Creative Commons Attribution 4.0 International License. The images or other third party material in this article are included in the article's Creative Commons license, unless indicated otherwise in the credit line; if the material is not included under the Creative Commons license, users will need to obtain permission from the license holder to reproduce the material. To view a copy of this license, visit http://creativecommons.org/licenses/by/4.0/

(C) The Author(s) 2017
} 